\title{
ECOLOGICAL PROTECTION OF AGRICULTURE THROUGH SERBIA'S LEGAL REGULATIONS AND JUDICIAL PRACTICE
}

\author{
Zdravko Petrović ${ }^{1}$, Vojislav Jovic $c^{2}$, Dragan Manojlovic ${ }^{3}$
}

\begin{abstract}
Within the codification of Crminal law of Republic of Serbia, which was conducted in 2005, legal protection of agriculture was introduced into ecological delicti which were then emphasised by having them unified in the sole Head of the Criminal code as well as by partially aggravating penal policy. Certain criminal offences, which prior to the codification were a part of a different field of legal protection, are now listed in the ecological delicti catalogue, and that positions them, according to the number of listed deliciti, on a very high place in comparisson to the other groups of criminal offences. Within the ecological delicti, there is a total of 18 (eighteen) offences, which are divided into 4 (four) groups depending on the object of legal protection. In this paper, besides the introductory conceptual defining the object of research, we described the normative arrangement of all the ecological delicti, within the agricultural protection, by researching their essential elements which include the capital and the qualified form of execution, perpetrators features, type of responsability and penalty. Empirical research covers the four year period, more precisely the years 2009 -2012, according to the parameters related to the number of adult persons accused for criminal offenses against the environment which are endangering agriculture, or the number of accused and convicted persons, shown globally and individually according to the structure criminal offenses. Furthermore the research includes the penal policy which reffers to the allready stated penalties, that is-jail sentences and their duration, and that also is depicted individually and globaly according to the criminal offences structure.
\end{abstract}

Key words: ecological protection, agriculture, criminal code, penal policy.

JEL: $K 14, K 32, Q 15$.

1 Zdravko Petrović, PhD., Full professor, Faculty of Law, Public Administration and Security, Bulevar umetnosti Street no. 29, 11070 Novi Beograd, Serbia, Phone:+381 63575880 , E-mail: zpetrovic@megatrend.edu.rs

2 Vojislav Jović, PhD., Assistant Professor, Faculty of Law, Public Administration and Security, Bulevar umetnosti Street no. 29, Novi Beograd, Serbia, Phone: +381 6313339 99, E-mail: vjovic@megatrend.edu.rs

3 Dragan Manojlović. PhD., Associate Professor, Faculty of Law, Public Administration and Security, Bulevar umetnosti Street no. 29, Novi Beograd, Serbia, Phone:+ 3816432219 26, E-mail: dmanojlovic@megatrend.edu.rs 


\section{Introduction}

Let us start from the conceptual identification of offence (delict), that is, its lexical, legal, criminal and sociological meaning. Lexically, the word delict is derived from the Latin word delinquere, that is, delictum, meaning an act against the law, an offence, crime (Vujaklija, 1980). Legally, it means a criminal offense which under the substantive law includes formal and objective-subjective concept, that is, determination of an offence under the law, its illegality and comitance of an offence (Lazarević, 2006). As per criminological aspect, its meaning is based on a multitude of terms used to designate an unlawful conduct that is the subject of criminological research, where the term delict equals with the terms crime and offence, being considered as an individual criminal behaviour (Ignjatović, 2007). Sociological interpretation of delict comprises asocial and anti-social behaviour that manifests as the rejection and opposition to the proclaimed or customary norms of the community, that is, behaviour that is deemed contrary to social order. Lexically, ecology entails biology and physiology (Ming, 1995) in the narrow sense; it is a science that studies interactions of animals and plants with their physical and abiotic environment and with one another. This paper focuses on environmental offences that within the criminal and legal framework differ from other offences in the distinctiveness of the object of protection (Lazarus, 2000).

The SubstantiveCriminal Code of the Republic of Serbia comprises 22 groups of standardized offences, which are classified under different chapters of the law. Environmental offences, that is, criminal offences against the environment are the sixth most numerous offences in the codified Criminal Code that has been in effect since 2006 (Criminal Code "Official Gazette of the Republic of Serbia“, No. 85/2005 and 111/2009).

Their distinctiveness, multidisciplinary approach and complexity is determined by the object of legal protection, which encompasses important ecological values such as: 1) right to live in healthy environment; 2) rational use of natural resources; 3 ) preservation of the integrity of biosphere; 4) protection from all forms of environmental pollution, 5) right of access to information on the environment and participation in decision making on important environmental issues; 6) protection of air, water and soil; 8) fauna and flora protection. Protection of the environment through criminal law is based on the concept of biocentric views of the environment, that assign essential importance for life to the environment, and therefore environment is considered as the protected asset per se, as opposed to the anthropocentric views that treat the environment as a resource that is subordinate to human needs (Lilić, Drenovak, 2010).

Environmental offences are characterized by their multiplicity, mutual diversity and distinctiveness of the modern crime (Bošković, 1996), and therefore they are classified into four categories: 1) general environmental offences 2) criminal offences pertaining to dangerous substances; 3 ) criminal offences against the wildlife and plants; 4) criminal offences pertaining to poaching game and poaching fish. 


\section{Methodology and Data Sources}

The data on juvenile and adult perpetrators of criminal offences, responsible persons and legal entities - perpetrators of economic violations were obtained from the regular statistical surveys. The data on courts and judges, public prosecutors' offices and public prosecutors were obtained from the Ministry of Justice and Public prosecutors' Council. Criminal offences are presented by criminal offences' groups according to the Classification of Criminal Offences determined by the Statistical Office of the Republic of Serbia.

The coverage of criminal offences, as socially negative phenomena, is complete since the statistical surveys comprise a) all adult perpetrators of criminal offences (including criminal offences made by unknowns as well), b) legal entities and persons in charge - perpetrators of economic violations, against whom a report was submitted to public prosecutor's office and against whom proceedings were conducted and legally closed (absolute decree rendered) with authorized public prosecutor offices and courts.

Adult perpetrators of criminal offences are persons who, at the time when criminal offence committed, were 18 and against whom the proceedings pursuant to crime report and preliminary proceedings were closed, accused persons against whom criminal proceedings were closed and decree irrevocably rendered, as well as persons sentenced. Reported person - known perpetrator is an adult perpetrator of criminal offence against whom proceedings by crime report and preliminary proceeding were closed by a decision: charges rejected, investigation suspended; investigation terminated; or charge sheet submitted.

Reported person - unknown perpetrator is an unknown person against whom crime report was submitted to public prosecutor's office, and who was not identified within one year following the crime report was submitted.Accused person is an adult against whom indictment, charge sheet, summary charge or private suit were instituted at court, and against whom criminal proceedings were closed by court decision rejecting private charge; proceedings were suspended or charge dismissed; perpetrator acquitted of charges; charges rejected, security measure passed without stating sentence or perpetrator pronounced guilty. Sentenced person is a convicted adult person who was pronounced guilty and sentenced to penalties: punishment, conditional sentence, judicial-admonition, security measure, corrective measure, as well as a person pronounced guilty but discharged, is considered to be a sentenced person.

The sources of data titled "Criminal charges" on the crimes against farming by the adult persons in the Republic of Serbia, were obtained on the basis of the research which was conducted using the Questionnaire CK-1" The Questionnaire for an adult against whom the legal proceeding was completed". The data on the crimes of the accused and convicted adults were obtained on the grounds of the research which was conducted using Questionnaire CK-2 "The Questionnaire for the accused and convicted adult against whom the final criminal proceedings was completed". 
The instruments of the research have encompassed all the adult persons in the Republic of Serbia against whom there was a reasonable suspicion of having committed an offence against farming and against whom the criminal charges were filed at the competent public prosecutor's office as well as those against whom statutory proceeding was conducted and completed.

The term adult offender relates to the offender who was 18 years old at the time crime was committed. The term type of decision (Questionnaire CK-1) implies the decision of the public prosecutor with which the legal proceedings were completed. The person reported relates to an adult person against whom criminal proceeding was conducted and lawsuit was filed due to the reasonable doubt that the person committed the offence. "The accused" is an adult person against whom indictment, proposition of the indictment or plaintiff was brought before the court. The convicted person refers to an adult person who was found guilty and against whom criminal sanctions were imposed. "Criminal offence" is the offence which has been prescribed by the law as the criminal act which is contrary to the law or committed against law.

By applying the method of content analysis, comparison, correlation and statistical research for a specified period, the number of submitted admission, indictments and verdicts issued in the Republic of Serbia, which will be observed trends in relation to the decisions of the courts and the capacity of the evidence and show how effectiveness legal protection of agriculture. The research is aimed at identifying the legal aspects of protection of agriculture in the Republic of Serbia, in the existing positive legal regulations, the scientific contributions that would highlight the shortcomings and potential modification de lege in future amendments to the legislation in this area.

\section{Enviromental offences and their characteristics}

As previously said, when the Criminal Code was codified all environmental offences were gathered in its separate chapter, what meant the standardization (Adler, 2005) of the protection of the environment through criminal law. On the other hand, certain regulations that regulate the area of administrative- legal protection, in addition to economic offences and felonies, also include criminal offences as a form of incrimination in the areas that regulate: 1) plant health protection; 2) production, trade and use of products for plant protection; 3 ) use and release into the environment of genetically modified organisms (Winter, 2008); and 4) water protection. We explore environmental offenses and their distinctiveness by describing and analyzing law provisions and theory of criminal justice, focusing on the definition and interpretation of their object of protection, that is, the particularities of certain qualifying characteristics.

\section{General environmental offences}

General environmental offences include protection of basic natural assets through criminal code, that is, protection of biosphere (Eggersz, Mackenzie, 2001), by standardizing certain anthropogenic activities that pose threat to environment. Theory of criminal law classifies 
seven criminal offences into general environmental offenses that according to the object of protection and other characteristics encompass: 1) Environmental pollution: A global object of protection is the environment as an imperative providing basic conditions for the survival of humankind, through joint protection of air, water and soil (Kraus, et. al., 1991). The act of committing basic form of criminal offence implies the pollution of air, water and soil to larger extent and over a wider area, by violating the regulations on protection, preservation and improvement of the environment. Pollution caused by man (by burning dangerous substances that pollute air, discharging wastewater into a receiving waterbody or soil, releasing or disposal of dangerous chemicals,...), results in air (Guadalupe,1996), water and soil becoming harmful to people's lives and health and the survival of flora and fauna.

Pollution of air, water and soil to larger extent or over a wider area is a threshold that separates criminal offence from minor offences, that is, from economic offence (Ming, 1995) and misdemeanours. The qualified form of criminal offence entails the pollution of air, water and soil which results in destruction of animal and plant life to large extent or environmental pollution in such extent that the clean-up requires longer period of time or great expense.

The elements of criminal offence that are necessary for determining whether basic or qualified form of the offence is committed, and which are not precisely identified by the law (greater extent, wider territory, longer time, higher expenses), as a rule, are established in every individual case based on the expert's opinion, that the competent judicial authority entrusted experts in their field. The offender who commits basic form of criminal offence with premeditation shall be punished cumulatively by imprisonment of six months to five years and a fine, or alternatively by a fine and imprisonment up to two years in the offence is committed from negligence.

For the qualified form of offence committed with premeditation the offender shall be cumulatively punished by imprisonment of one to eight years and a fine, or cumulatively by imprisonment of six months to five years and a fine if the offence is committed from negligence. 2) Failure to undertake environmental protection measures: Unlike the previous criminal offense that can be committed by any offender, this offence can be committed solely by an official or a responsible officer, by failing to undertake, or carry out the protection measures prescribed by the law or by the decision passed by the competent authority.

The consequence of this criminal offence can be abstract or realistic, meaning that the offence is committed once the offender fails to undertake the protection measures regardless of the fact that the offence hasn't resulted in a consequence, and that is its basic form of incrimination for which the offender shall be punished by a fine or imprisonment up to three years if the offence is committed with premeditation or alternatively by a fine or imprisonment up to one year if the offence is committed from negligence.

In case the offence results in a consequence, the offender may receive a more severe sentence, in line with the provisions regulating the criminal offence pertaining to environmental pollution. 3) Illegal construction and operation of facilities and installations polluting the environment: This criminal offence, which can also be committed solely by an official or a responsible officer, entails allowing or issuing an approval for construction, start-up or 
operation of facilities and installations or use of technologies, contrary to regulations on environmental protection (Schoenbaum,1992), preservation and improvement, that to larger extent and over a wider area pollute the environment.

The offence is committed by doing, or allowing, approving or accepting, as well as by failing to undertake or carry out legally prescribed obligations that most often refer to inspection and monitoring activities. The basic form of criminal offence, which can be committed only with premeditation, encompasses the environmental pollution to larger extent and over a wider area, and the penalty prescribed for an offence includes imprisonment of six months to five years. The qualified form of the offence, which can also be committed only with premeditation, entails the severity and the extent of pollution which are threshold for criminal offense pertaining to environmental pollution, and the penalty prescribed for an offence includes imprisonment of one to eight years. 4) Damaging environmental protection facilities and installations: This criminal offence is specific because it can be committed in ideal concurrence, and as a rule the offender shall be punished for this criminal offence only, given that other concurrent offences usually fall within minor offences (theft, destruction and damage to the property of others).

The criminal offence, which can be committed by any person, includes damage (partial destruction which reduces operability of facilities or installations), destruction (complete destruction which makes inoperable facilities or installations), removal or otherwise making inoperable facilities or installations for environmental protection (Torres, Kan, 1985). If the offender commits basic form of criminal offence with premeditation, he shall be punished by imprisonment up to three years, or alternatively a fine or imprisonment up to one year if the offence is committed from negligence.

The qualified form of the offence entails the severity and the extent of environmental pollution which is threshold for criminal offense pertaining to environmental pollution and the respective penalty prescribed, in case the offence is committed with premeditation or from negligence. 5) Damaging the environment: Alternatively, this criminal offence encompasses unlawful exploitation of natural resources (exploitation of forests, water, soil, and minerals), unlawful construction of buildings, executing certain works (installation of dams, ploughing the soil, watercourse diversion) or otherwise causing damage to the environment. Thus, this criminal offence, which can be committed by any person, does not result in the environmental pollution, unlike the previous criminal offences, but in causing damage to the environment, including the natural habitat degradation.

The law stipulates only the basic form of criminal offence, which entails the damage to the environment to large extent and over a wider area, and the penalty prescribed for an offence includes imprisonment up to three years if the offence is committed with premeditation, that is, a fine or imprisonment up to one year if the offense is committed from negligence. 6) Destruction, damage, transfer into a foreign country or into Serbia of protected natural asset: The object of legal protection is the protected natural asset that is considered as a preserved part of the nature with special values and qualities (geodiversity, biodiversity, scenery, landscapes etc.), which has a permanent ecological, scientific, cultural, educational, 
recreational, tourist and other importance, and therefore is subject to special protection as a natural asset of great importance.

If the offender commits basic form of criminal offence which includes destruction or causing damage to a protected natural asset, he shall be punished by imprisonment of six months to five years, if the offence is committed with premeditation, or alternatively by a fine or imprisonment up to six months if the offence is committed from negligence. Another basic form of criminal offence entails unlawfully taking abroad a rigorously protected or protected plant or animal species, that is, importing or bringing into Serbia a foreign plant or animal species protected under international treaties and documents, regardless of the manner in which taking abroad or bringing in is done, the extent and motives.

The penalty prescribed for this form of criminal offense, for which an attempt is also punishable, includes cumulatively imprisonment of three months to three years and a fine, while a rigorously protected or protected plant and animal species shall be seized ("Official Gazette of the Republic of Serbia“", No. 5/2010). 7) Violation of the right to be informed on the state of the environment: The object of legal protection is the right to be informed on the state of the environment, as a right guaranteed by the Constitution of the Republic of Serbia.

This criminal offence alternatively entails unlawfully withholding information or giving false information on the state of the environment and events that is required for evaluation of environmental hazard and undertaking of protection measures. The penalty alternatively prescribed for this criminal offence, which can be committed solely by an official or a responsible officer and with premeditation, includes a fine or imprisonment up to one year.

\section{Environmental offences pertaining to dangerous substances}

Two criminal offences fall within environmental offences pertaining to dangerous substances: 1) Bringing dangerous substances into Serbia and unlawful processing, depositing and stockpiling of dangerous substances: Basic forms of this criminal offence entail unlawfully bringing into Serbia radioactive or other hazardous materials or hazardous waste, and their transport, processing, disposal, collecting or stockpiling, that is, allowing or facilitating by abuse of position or powers, bringing into Serbia of such materials, their transport, processing, disposal, collecting or stockpiling.

Whoever contrary to regulations brings into or transports, processes, collects or stockpiles such materials shall be punished by imprisonment of six months to five years and a fine, while any official or a responsible officer who by abuse of his position or powers allows or facilitates some of the above mentioned unlawful activities, shall be punished by imprisonment of one to eight years and a fine.

The qualified forms of the offence entail destruction of animal and plant life to high extent as a consequence of bringing into or transporting, processing, collecting or stockpiling of dangerous substances, for which the penalty prescribed includes imprisonment of two to ten years and a fine, that is, if the mentioned offenses are committed by organized group of persons, the offenders 
shall be punished by imprisonment of three to ten years and a fine. 2) Illegal construction of nuclear plants: The incrimination entails construction or permitting the construction of nuclear power plant or a nuclear fuel production plant, or processing plant for used nuclear fuel, for which the penalty prescribed includes imprisonment of six months to five years.

\section{Environmental offences against wildlife and plants}

Seven criminal offences encompass environmental offences against wildlife and plants: 1) Killing and wanton harming of animals: The object of legal protection, as a rule, refers to domestic and wild animals, that is, animals that can feel pain, fear, suffering or stress. The basic form of criminal offence entails killing, injuring, torturing or otherwise harming an animal, for which the penalty prescribed includes a fine or imprisonment up to one year. The qualified forms of offense entail killing, injuring or torturing a number of animals or if the offence is committed against animals belonging to specially protected species, for which the alternative penalty prescribed includes a fine or imprisonment up to three years, or if offender with gain as a motive organises or finances animal fights between animals of the same of different species, he shall be punished cumulatively with imprisonment up to three years and a fine. 2) Transmitting of contagious plant and animal diseases: The criminal offence entails failing to observe regulations, decisions or orders issued by an authorized body on undertaking measures during an epidemic of livestock disease that may endanger cattle breeding, or during threat of disease or pests that may endanger plant life. If the offender commits basic forms of this criminal offence, he shall be punished by a fine or imprisonment up to two years as an alternative sanction.

The qualified form of the offence is committed if it results in death of animals, destruction of plants or other considerable damage due to the failure to act, for which the penalty prescribed includes imprisonment up to three years. 3) Malpractice in veterinary services: This criminal offence can be committed only by a veterinarian or licensed veterinary technician, and it entails application of an obviously inadequate means or method of treatment of animals, thereby causing death of animals or other considerable damage, for which the penalty prescribed includes a fine or imprisonment up to two years if the offence is committed with premeditation, that is, a fine or imprisonment up to six months if the offence is committed from negligence. 4) Producing harmful products for treating animals: Alternatively, the basic form of this criminal offense entails production for sale or putting into circulation products for treatment or prevention of disease of animals that are dangerous to life and health of animals, for which the penalty prescribed includes a fine or imprisonment up to one year. The qualified form of offence is committed if it results in death of animals or other considerable damage due to use of harmful products, for which the penalty prescribed includes a fine or imprisonment up to two years, while the penalty prescribed for basic and qualified form of offence that is committed from negligence includes a fine or imprisonment up to six months. 5) Pollution of livestock fodder and water:

The basic forms of incrimination entail contamination of livestock fodder and water, by using a harmful substance, that is, contamination of water in fish-pond (Hedemann, 2000) lake, river or canal thereby causing danger to survival of fish or other aquatic animals, for which 
the penalty prescribed includes a fine or imprisonment up to two years. It the contamination results in death of animals, the offence is considered as the qualified form, for which the penalty prescribed includes a fine or imprisonment up to three years.

If the offender commits basic or qualified form of criminal offence from negligence, he shall be punished by a fine or imprisonment up to six months. 6) Devastation of forests: The general form of criminal offence entails unlawful cutting and clearing of forests or damaging trunks, or cutting down one or more trees in a park, avenue of trees or elsewhere where cutting down of trees is prohibited, for which the penalty prescribed includes a fine or imprisonment up to one year. The qualified form entails committing of offense in a protected forest, national park or other forest intended for special purpose, for which the penalty prescribed includes imprisonment of three months to three years. 7) Forest theft: The basic form of criminal offence entails felling one or more trees in a forest, park or avenue of trees, by reason of theft, and the quantity of timber doesn't exceed one cubic meter, for which the penalty prescribed includes a fine or imprisonment up to one years.

The offender commits the qualified form of the offence if the quantity of felled timber he intends to sell exceeds five cubic meters or if the offence is committed in a protected forest, national park or other forest intended for special purpose, and shall be punished by a fine or imprisonment up to three years.

\section{Environmental offences pertaining to hunting and fishing}

Environmental offences pertaining to hunting and fishing comprise two criminal offences: 1) Poaching game: The basic forms of this criminal offence entail hunting game during closed season or in the territory where hunting is prohibited, and the penalty prescribed for an offence includes a fine or imprisonment up to six months, that is, poaching on another's hunting preserve and killing, wounding game or catching it alive, and the penalty prescribed for an offence includes a fine or imprisonment up to one year.

The qualified forms of the offence are committed when the offence is committed against big game, and the penalty prescribed includes a fine or imprisonment up to two years, that is, when the offender hunts game whose hunting is prohibited or hunts particular game without a special permit when such permit is required (Ruhl, 2009) or hunts with means which destroy game in large numbers, for which the penalty prescribed includes imprisonment up to three years.

The measure of seizing the bagged game and hunting implements is applied in case of all forms of this criminal offence. 2) Poaching fish: It is the object of protection that makes difference between the basic form (Tribe, 1974) of this criminal offense and the criminal offense pertaining to poaching game, and in the case of this criminal offence the object of protection is fish and other aquatic animals. The qualified forms of the offense entail fishing or catching aquatic animals by explosive, electricity, poison, stunning or in manner otherwise damaging to breeding of such fauna or whereby mass destruction (Royal, 1997 ) of such fauna results, that is, catching fish or other aquatic animals of significant biological value or in larger quantity, for which the penalty prescribed includes imprisonment up to three years. 


\section{Methodos and materials in empirical research}

An empirical research covers a four-year period, from 2009 to 2012, in terms of data including: reported adults, dismissed criminal charges, indicted persons, convicted persons, as well as the type and the severity of the pronounced sentence. Based on the figures presented in the ( Table No.1), we find that the share of reported persons for criminal offenses against the environment accounts for $2 \%$ of the total number of reported persons for all criminal offences.

One of the reasons why the number of reported persons is so low, and the same goes for the number of detected criminal offences in this area, surely lies in the fact that the manner of collecting evidence in this area is pretty specific and is usually based on the experts' opinions. Therefore, according to experts and scholars, it is more than necessary to set up teams of environmental forensics experts (Čavoški, 2011).

Table 1. Overall number of persons reported for all offences and number of persons reported persons for criminal offences against the environment.

\begin{tabular}{|l|c|c|c|c|}
\hline \multicolumn{1}{|c|}{ Year } & $\mathbf{2 0 0 9}$ & $\mathbf{2 0 1 0}$ & $\mathbf{2 0 1 1}$ & $\mathbf{2 0 1 2}$ \\
\hline $\begin{array}{l}\text { Overall number of persons reported for all } \\
\text { offences }\end{array}$ & 100,026 & 74,279 & 88,207 & 92,879 \\
\hline $\begin{array}{l}\text { Persons reported for criminal offences against } \\
\text { the environment }\end{array}$ & 2,081 & 1,568 & 1,789 & 1,841 \\
\hline
\end{tabular}

Source: Bulletin No. 578 \& 588. ISSN 0354-3641. Republic Statistical Office of the Republic of Serbia.

The research findings displayed in the (Table No. 2) suggest that the biggest number of persons is reported for criminal offences pertaining to forest theft, accounting for $70 \%$ of the total number of persons reported for criminal offences against the environment.

Table 2. Number of persons reported for criminal offences against the environment in terms of the structure of the offense.

\begin{tabular}{|l|c|c|c|c|}
\hline \multicolumn{1}{|c|}{ Year } & $\mathbf{2 0 0 9}$ & $\mathbf{2 0 1 0}$ & $\mathbf{2 0 1 1}$ & $\mathbf{2 0 1 2}$ \\
\hline Environmental pollution & 16 & 7 & 12 & 8 \\
\hline Failure to undertake environmental protection measures & 8 & 4 & 8 & 1 \\
\hline Damaging the environment & 16 & 8 & 6 & 16 \\
\hline $\begin{array}{l}\text { Destruction, damage, transfer into a foreign country or into } \\
\text { Serbia of protected natural asset }\end{array}$ & 2 & 93 & 8 & 10 \\
\hline Killing and wanton harming of animals & 116 & 123 & 196 & 178 \\
\hline Transmitting of contagious animal and plant diseases & 5 & 4 & 6 & $/$ \\
\hline Malpractice in veterinary services & 2 & 2 & 1 & 2 \\
\hline Pollution of livestock fodder and water & 12 & 5 & 3 & 10 \\
\hline Devastation of forests & 157 & 69 & 89 & 103 \\
\hline Forest theft & 1,462 & 1,090 & 1,262 & 1,276 \\
\hline Poaching game & 172 & 99 & 129 & 173 \\
\hline Poaching fish & 111 & 63 & 60 & 60 \\
\hline
\end{tabular}

Source: Bulletin No. 578 \& 588. ISSN 0354-3641. Republic Statistical Office of the Republic of Serbia. 
The number of persons reported for criminal offences that fall within the group of general offences against the environment and usually pose the most immediate threat to the environment, account for approximately $3 \%$, and that is surely disturbing given the impact of anthropogenic factors on the overall state of the environment.

The figures displayed in the (Table No. 3) indicate that $45 \%$ of the total number of persons reported for all criminal offenses against the environment is actually indicted.

Table 3. Number of persons indicted for criminal offences against the environment

\begin{tabular}{|c|c|c|c|c|}
\hline Year & $\mathbf{2 0 0 9}$ & $\mathbf{2 0 1 0}$ & $\mathbf{2 0 1 1}$ & $\mathbf{2 0 1 2}$ \\
\hline Persons indicted for criminal offences against the environment & 1,068 & 917 & 635 & 632 \\
\hline
\end{tabular}

Source: Bulletin No. 578 \& 588. ISSN 0354-3641. Republic Statistical Office of the Republic of Serbia.

Based on the analysis of certain elements from the (Table No. 4) the research confirms the previous findings pertaining to correlation of the persons reported in terms of structure of criminal offences, that is, the fact that the biggest number of reported persons is indicted for criminal offence pertaining to forest theft (around 74\%), and that the number of persons indicted for criminal offenses that fall within the group of general offences against the environment accounts for approximately $2 \%$.

Table 4. Number of persons indicted for criminal offences against the environment in terms of the structure of offense.

\begin{tabular}{|l|c|c|c|c|}
\hline \multicolumn{1}{|c|}{ Year } & $\mathbf{2 0 0 9}$ & $\mathbf{2 0 1 0}$ & $\mathbf{2 0 1 1}$ & $\mathbf{2 0 1 2}$ \\
\hline Environmental pollution & 5 & $/$ & 2 & 7 \\
\hline Failure to undertake environmental protection measures & 2 & 2 & 6 & 1 \\
\hline Damaging the environment & 2 & 2 & 4 & 7 \\
\hline $\begin{array}{l}\text { Destruction, damage, transfer into a foreign country or into } \\
\text { Serbia of protected natural asset }\end{array}$ & 6 & 5 & 2 & 4 \\
\hline Killing and wanton harming of animals & 33 & 28 & 38 & 43 \\
\hline Transmitting of contagious animal and plant diseases & 2 & $/$ & 2 & 3 \\
\hline Malpractice in veterinary services & 4 & $/$ & $/$ & $/$ \\
\hline Producing harmful products for treating animals & $/$ & 1 & 1 & $/$ \\
\hline Pollution of livestock fodder and water & 2 & & 2 & 2 \\
\hline Devastation of forests & 77 & 38 & 36 & 49 \\
\hline Forest theft & 787 & 766 & 417 & 421 \\
\hline Poaching game & 74 & 23 & 46 & 49 \\
\hline Poaching fish & 74 & 51 & 78 & 44 \\
\hline
\end{tabular}

Source: Bulletin No. 578 \& 588. ISSN 0354-3641. Republic Statistical Office of the Republic of Serbia.

The figures displayed in the (Table No. 5) indicate that $63 \%$ out of the total number of persons indicted for criminal offences against the environment are convicted, that is, about $28 \%$ out of the total number of persons reported for these criminal offences. 
Table 5. Number of persons convicted for criminal offenses against the environment.

\begin{tabular}{|c|c|c|c|c|}
\hline Year & $\mathbf{2 0 0 9}$ & $\mathbf{2 0 1 0}$ & $\mathbf{2 0 1 1}$ & $\mathbf{2 0 1 2}$ \\
\hline $\begin{array}{l}\text { Persons convicted for criminal offences against the } \\
\text { environment }\end{array}$ & 835 & 333 & 449 & 430 \\
\hline
\end{tabular}

Source: Bulletin No. 578 \& 588. ISSN 0354-3641. Republic Statistical Office of the Republic of Serbia.

Further findings referring to convicted persons in terms of the structure of criminal offences, which are displayed in the (Table No. 6 ) confirm the logical trend that indicates that the biggest number of persons is convicted for criminal offence pertaining to forest theft (around 68\%) and that the number of persons who are convicted for general criminal offences against the environment is negligible and amounts to approximately $1.8 \%$.

Table 6. Number of persons convicted for criminal offences against the environment in terms of the structure of the criminal offenses.

\begin{tabular}{|l|c|c|c|c|}
\hline \multicolumn{1}{|c|}{ Year } & $\mathbf{2 0 0 9}$ & $\mathbf{2 0 1 0}$ & $\mathbf{2 0 1 1}$ & $\mathbf{2 0 1 2}$ \\
\hline Environmental pollution & 1 & $/$ & $/$ & $/$ \\
\hline Failure to undertake environmental protection measures & $/$ & 1 & 4 & 1 \\
\hline Damaging the environment & 2 & 2 & 3 & 6 \\
\hline $\begin{array}{l}\text { Destruction, damage, transfer into a foreign country or into } \\
\text { Serbia of protected natural asset }\end{array}$ & 6 & 5 & 2 & 4 \\
\hline Killing and wanton harming of animals & 28 & 22 & 27 & 23 \\
\hline Transmitting of contagious animal and plant diseases & 1 & $/$ & 1 & 1 \\
\hline Pollution of livestock fodder and water & 2 & $/$ & $/$ & $/$ \\
\hline Devastation of forests & 69 & 19 & 30 & 36 \\
\hline Forest theft & 616 & 218 & 287 & 297 \\
\hline Poaching game & 45 & 16 & 25 & 27 \\
\hline Poaching fish & 65 & 48 & 68 & 33 \\
\hline
\end{tabular}

Source: Bulletin No. 578 \& 588. ISSN 0354-3641. Republic Statistical Office of the Republic of Serbia.

The figures displayed in the (Table No. 7) suggest that only $9.5 \%$ of the total number of persons convicted for all criminal offences against the environment in the respective period was sentenced to imprisonment.

Table 7. Number of persons sentenced to imprisonment for criminal offences against the environment.

\begin{tabular}{|c|c|c|c|c|}
\hline Year & $\mathbf{2 0 0 9}$ & $\mathbf{2 0 1 0}$ & $\mathbf{2 0 1 1}$ & $\mathbf{2 0 1 2}$ \\
\hline Number of persons sentenced to imprisonment & 66 & 33 & 46 & 52 \\
\hline
\end{tabular}

Source: Bulletin No. 578 \& 588. ISSN 0354-3641. Republic Statistical Office of the Republic of Serbia,

As for the length of prison sentence and the structure of criminal offences for which it was pronounced, figures displayed in the (Table No. 8) indicate that the majority of 
convicted persons was sentenced to two to three months imprisonment (about 30\%), as opposed to two to three years imprisonment (about 1\%).

Table 8. Number of persons who received a prison sentence for criminal offences against the environment in terms of the structure of the criminal offenses and the length of prison sentence.

\begin{tabular}{|l|c|c|c|c|c|c|}
\hline \multicolumn{1}{|c|}{ Length of prison sentence } & $\begin{array}{c}\mathbf{2 - 3} \\
\text { years }\end{array}$ & $\begin{array}{c}\mathbf{1 - 2} \\
\text { years }\end{array}$ & $\begin{array}{c}\mathbf{6 - 1 2} \\
\text { months }\end{array}$ & $\begin{array}{c}\mathbf{3 - 6} \\
\text { months }\end{array}$ & $\begin{array}{c}\mathbf{2 - 3} \\
\text { months }\end{array}$ & $\begin{array}{c}\text { do 2 } \\
\text { months }\end{array}$ \\
\hline $\begin{array}{l}\text { Failure to undertake } \\
\text { environmental protection } \\
\text { measures }\end{array}$ & 1 & 1 & $/$ & 1 & $/$ & $/$ \\
\hline Damaging the environment & $/$ & 2 & 1 & 1 & $/$ & $/$ \\
\hline $\begin{array}{l}\text { Illegal construction of nuclear } \\
\text { plants }\end{array}$ & $/$ & 1 & $/$ & $/$ & $/$ & $/$ \\
\hline $\begin{array}{l}\text { Killing and wanton harming of } \\
\text { animals }\end{array}$ & $/$ & $/$ & $/$ & 2 & 1 & $/$ \\
\hline $\begin{array}{l}\text { Pollution of livestock fodder and } \\
\text { water }\end{array}$ & $/$ & $/$ & $/$ & 1 & $/$ & $/$ \\
\hline Devastation of forests & $/$ & $/$ & 3 & 1 & 1 & 3 \\
\hline Forest theft & $/$ & 5 & 11 & 38 & 46 & 43 \\
\hline Poaching game & 1 & 1 & 1 & 3 & 1 & \\
\hline Poaching fish & $/$ & $/$ & 3 & 4 & 9 & 6 \\
\hline
\end{tabular}

Source: Bulletin No. 578 \& 588. ISSN 0354-3641. Republic Statistical Office of the Republic of Serbia,

\section{Conclusion}

The importance of the overall protection, preservation and improvement of the environment was particularly brought into focus at the turn of the $20^{\text {th }}$ and $21^{\text {st }}$ centuries when some studies pointed at unforeseeable consequences that might occur as a result of the uncontrolled human impact on the environment. Man as a living being on the planet Earth put his right to freedom of behaviour above the laws of nature, thus placing himself above the nature. Man justifies his impact on ecology with his need for economic development that is determined by the exploitation of natural resources; nevertheless, that need is opposed to the concept of sustainable development, which implies a strictly controlled use of natural resources, especially those ones which fall within the category of non-renewable ones. The efforts that the responsible part of humankind invests into putting human impact on ecology under control are reflected in the fact that numerous important, international legal standards in the field of environmental protection were adopted thus creating a prerequisite for a wider introduction of the human impact on the environment in the legal framework. In line with these efforts, the Republic of Serbia gathered all criminal offences against the environment under one chapter of the Criminal Code that was codified in 2005 and partially tightened the penal policy. Formally, it can be concluded that the protection of the environment through Criminal Code is adequate. On the other hand, practically speaking and given the findings of 
the above empirical research, one may conclude that there is an obvious discrepancy between the formal legal norms and the implementation of the provisions of the Criminal Code in practice. Namely, the research findings indicate that the percentage of persons convicted for criminal offences against the environment is pretty low, compared to the number of persons reported for those offenses, as well as that there is an insufficient number of detected criminal offences falling within the group of general offences that pose the biggest threat to environment, and a negligible percent of persons who are convicted for such criminal offences. Further on, based on the research findings on the type and the length of the pronounced criminal sanctions, it is evident that mild penal policy doesn't achieve its objective that aims at prevention and repression. Based on the above mentioned, we tend to believe that the responsible part of humankind is to persist in its efforts to persuade or prevent other part of humankind "to saw off the branch they are sitting on".

\section{Literature}

1. Adler, H. J. (2005): Judicial Federalism and The Future of Federal Environmental Regulation Case Western Reserve University School of Law, Law Review, Iowa, United States, vol. 90, no. 2, pp. 379-473

2. Bošković, M. (1996): Kriminalistička metodika, Policijska akademija, Beograd, Srbija.

3. Eggersz, B., Mackenzie, R. (2001): The Cartagena Protocol on biosafety, Institute of International Economic Law, New Jersey Avenue, Oxford Journals Law \& Social Sciences, Washington DC, United States, vol. 3, no. 3, pp. 525-543.

4. Fögen, M. T. (1994): "Legislation in Byzantium: A Political and a Bureaucratic Technique", Law and Society in Byzantium. Dumbarton Oaks. ISBN 0-88402-2226.

5. Guadalupe, T. L. (1996): Agricultural Underdogs and International Agremeents: The Legal Context of Agricultural Workers within the Rural Economy, Law Review No. 9, New Mexico, Mexico.

6. Hedemann, R. M. (2000): Defending the Consumer's Right to a Clean Environment in the Face of Globalisation: The Case of Extraterritorial Environmental Protection Under European Community Law, Journal of Consumer Policy, Volume 23, no. 1, pp- 25-61.7. Ignjatović, Đ. (2007): Kriminologija, Dosije, Beograd, Srbija.

8. Kraus, B., Srzentić, N, Lazarević, Lj., Djordjević, M., Stajić, A. (1991): Komentar krivičnog zakonika Republike Srbije, Savremena administracija, Beograd, Srbija.

9. Lazarević, Lj. (2006): Komentar krivičnog zakonika Republike Srbije, Savremena administracija, Beograd, Srbija.

10.Lazarus, R. J. (2000): Restoring What's Environmental About Environmental Law in the Supreme Court, Georgetown University Law Center, UCLA Law Review, Georgetown, United States, Vol. 47, No. 3. 
11.Lilić, S., Drenovak, M. (2010): Ekološko pravo, Pravni fakultet u Beogradu, Beograd, Srbija.

12. Ming, C. J. (1995): Get Green or Get Out: Decoupling Environmental from Economic Objectives in Agricultural Regulation, Oklahoma Law Review, Michigan State University - College of Law, United States, vol. 48. p. 333.

13. Bilten broj 578,588, Republički zavod za statistiku Republike Srbije, Beograd, Srbija. ISSN 0354-3641.

14. Royal, C. G. (1997): Taking the Principle of Just Compensation Abroad: Private Property Rights, National Sovereignty, and the Cost of Environmental Protection, University of Cincinnati Law Review, Stetson University College of Law, United States, vol. 65, p. 539.

15. Ruhl, B. J.(2009): Thinking of Environmental Law as a Complex Adaptive System: How to Clean Up the Environment by Making a Mess of Environmental Law, Houston Law Review, Law Vanderbilt University - Law School, United States, vol. 34, no. 4.

16. Schoenbaum, T. (1992): Free International Trade and Protection of the Environment: Irreconcilable Conflict?, The American Journal of International Law, United States, vol. 86, no. 4, pp. 700-727.

17. Tribe, H. L. (1974): Ways Not to Think about Plastic Trees: New Foundations for Environmental Law, The Yale Law Journal, United States, vol. 83, no. 7, pp. 13151348.

18. Torres, G., Kan, L. (1985): Wetlands and Agriculture: Environmental Regulation and the Limits of Private Property, Law. Review, United States, no. 34, p. 539.

19.Čavoški, A. (2011): Analiza prikupljene statistike o postupanju tužilaštva u oblasti životne sredine. Priručnik za zaštitu životne sredine, Udruženje javnih tužilaca i zamenika javnih tužilaca, Beograd, Srbija.

20. Winter, G.(2008): Nature Protection and the Introduction into the Environment of Genetically Modified Organisms: Risk Analysis in EC Multilevel Governance, Review of European Community \& International Environmental Law, vol. 17, no. 2, pp. 205-220.

21.Vujaklija, M. (1980): Leksikon stranih reči i izraza, Prosveta, Beograd, Srbija.

Legislation and websites:

1. Krivični zakonik Republike Srbije, "Službeni glasnik Republike Srbije“, br. 85/2005 and $111 / 2009$.

2. Uredba o proglašenju $i$ zaštiti strogo zaštićenih $i$ zaštićenih divljih vrsta biljaka, životinja i gljiva, "Službeni glasnik Republike Srbije“, No. 5/2010. 


\title{
EKOLOŠKA ZAŠTITE POLJOPRIVREDE U PRAVNOJ REGULATIVI I SUDSKOJ PRAKSI REPUBLIKE SRBIJE
}

\author{
Zdravko Petrovićt, Vojislav Jovićs, Dragan Manojlović ${ }^{6}$
}

\begin{abstract}
Rezime
U okviru kodifikacije materijalnog krivičnog zakonodavstva Republike Srbije koja je izvršena 2005. godine, pravna zaštita poljoprivrede ušla je u ekološke delikte koji su dobili na svom značaju, pre svega njihovim normiranjem u okviru jedinstvene glave zakona $i$ delimičnim pooštravanjem kaznene politike. Pojedina krivična dela koja su pre kodifikacije pripadala drugoj oblasti pravne zaštite, svrstana su u katalog ekoloških delikata, čime su ovi delikti po broju normiranih, zauzeli visoko mesto u odnosu na ostale grupe krivičnih dela. U okviru ekoloških delikata svrstano je ukupno osamnaest krivičnih dela, podeljenih u četiri grupe u zavisnosti od objekta pravne zaštite. U ovom radu je pored uvodnog pojmovnog određenja predmeta istraživanja, izvršena deskripcija normativnog uređenja svih ekoloških delikata, pri zaštiti poljoprivrede, istraživanjem njihovih osnovnih elemenata koji obuhvataju radnju izvršenja osnovnog i kvalifikovanog oblika, svojstvo učinioca, oblik vinosti i propisanu kaznu. Empirijsko istraživanje obuhvata četvorogodišnji period, odnosno period od 2009. do 2012. godine, po parametrima koji se odnose na broj prijavljenih punoletnih lica za krivična dela protiv kojima se ugrožava poljoprivreda, odnosno broj optuženih i osuđenih lica, prikazanim globalno i pojedinačno po strukturi krivičnih dela. Nadalje istraživanje obuhvata kaznenu politiku koja se odnosi na izrečene krivične sankcije, odnosno izrečene kazne zatvora i njihovu visinu, takođe prikazane globalno i pojedinačno po strukturi krivičnih dela.
\end{abstract}

Ključne reči: ekološka zaštita, poljopriovreda, krivično zakonodavstvo, kaznena politika.

4 Redovni profesor, dr Zdravko Petrović, Fakultet za pravo, javnu upravu i bezbednost, Bulevar umetnosti 29, 11070 Novi Beograd, Srbija, tel. +381 63575 880, E-mail: zpetrovic@megatrend.edu.rs

5 Docent, dr Vojislav Jović, Fakultet za pravo, javnu upravu i bezbednost, Bulevar umetnosti 29, Novi Beograd, Srbija, tel. +381 63133 39 99, E-mail: vjovic@megatrend.edu.rs

6 Vanredni profesor, dr Dragan Manojlović, Fakultet za pravo, javnu upravu i bezbednost, Bulevar umetnosti 29, Novi Beograd, Srbija, tel. 38164322 19 26, E-mail: dmanojlovic@megatrend.edu.rs 